\title{
Motivation and benefits of implementation and certification according ISO 9001 - the Portuguese experience
}

\author{
G. Santos ${ }^{1 *}$, B. Costa ${ }^{2}$, A. Leal ${ }^{3}$ \\ ${ }^{1}$ College of Technology, Polytechnic Institute Cavado Ave, PORTUGAL \\ ${ }^{2}$ College of Management, Polytechnic Institute Cavado Ave, PORTUGAL \\ ${ }^{3}$ Faculty of Business and Economic Science, University of Seville, SPAIN \\ "Corresponding Author: e-mail: gsantos@ipca.pt, Tel +351-253-802260, Fax. +351-253-823127
}

\begin{abstract}
The aim of the research is to analyze the different aspects associated with the motivation and benefits of certified ISO 9001 companies in Portugal. A total of 426 certified Portuguese companies were surveyed. The response rate was equal to 61.03 percent. Our results suggest that the main motivation for certification were "improvement of quality", "improvement of company image", "marketing advantage", "give empowerment to workers / capturing workers knowledge" and "cost reduction". The main benefits that Portuguese companies have gained from the referred certification have been, among others, the improvement of "procedures", beneficial effect on the "company's image", the improvement of quality products/services, increase of the "customer satisfaction", improvement of "on-time delivery"; improvement the "morale" of workers' increase in productivity and decrease of "production costs", among others. The surveyed firms belong only to the Minho region of the north of Portugal. This paper aims to provide a contribution to the research related to the motivation and benefits associated to the quality management systems. The selection of the motives and benefits were validated through statistical analysis and the relationship between expected and perceived benefits was discussed.
\end{abstract}

Keywords: Quality Management Systems (QMS); ISO 9001; Benefits of certification; Portugal.

DOI: http://dx.doi.org/10.4314/ijest.v6i5.1

\section{Introduction}

The strong competitiveness of the world market has caused the quality to become a growing demand of markets and customers. Companies have been forced to open its doors to the culture of quality, a message that is often associated with the ISO 9001 (Casadesus, 2001). ISO 9000 is first and foremost based on systematic prescriptions aimed at better responding to customer requirements, implementing more efficient management practices for quality, and continually improving performances (Boiral, 2012 ,a).There is a general concern regarding the contribution of ISO 9001 towards quality improvement and customer satisfaction, despite the exponential increase in the number of certified companies. There are many reasons provided by companies when justifying their decision to obtain ISO 9001 certificate. The requirement of customers and the access to new markets has traditionally been the alleged reasons (Escanciano et al., 2001). But the arguments raised by companies already certified, when recommending the certification to other companies, regardless of what have been their own reasons to certify, identify the benefits of all types, derived from obtaining certification (Escanciano, 2000). According to Heras-Saizarbitoria (2013,b), ISO 9000 certification in SMEs can be compared to the acquisition of an organisational degree whose optimistic rhetoric and similar institutional pressures mask the considerable heterogeneity of certified organisations and elasticity of the standard when integrated into daily activities. Thus, Boiral $(2012, a)$ stats that developed and upgraded by international experts of the field in order to integrate the best practices for quality management, ISO 9000 is clearly projected as an efficient and proven management system.

Studies indicate that, while the main motivations for firms to certify their quality systems are related with the markets, the benefits are generally the improvement of the internal organization and reporting procedures and quality improvements (Lipovatz 
et al., 1999), but to do it, according to Lee et al. (1999), after certification, the companies' task is to change the quality`s culture throughout the company. Jones et al. (1997) take in account previous work in their analysis and conclude in accordance with Leung et al. (1999), that there is a relationship between the company's initial motivation for certification and its perception of the received benefits, so companies that obtain the certification for external reasons get less benefits then companies that obtain the certification for internal reasons, despite finding also internal benefits (Jones, 2000). The implementation of a quality management system, and its subsequent certification, is a voluntary process, supported by the organisation's own motivations, goals and policies (Sampaio, 2009). According Heras-Saizarbitoria (2013,a), management system standards, also called meta-standards, have been adopted by an increasing number of organizations across the world. Although these management system standards are based on the same type of management principles and institutional arrangements, the literature remains scattered, with diverse studies focused on specific standards and published in various journals. But ISO 9000 certification can have different meanings and realities depending on the organizations and individuals involved (Boiral, 2012,b).

\section{Literature review}

A literature review conducted by Escanciano et al. (2001) allowed compile many different benefits, such as: attract new customers; increase customer's loyalty; increase customer's satisfaction; improve the understanding of customer's needs and expectations; increase sales; increase their share in the market; increase exportation; increase productivity, improve the company's image in the market; improve the quality of the products and/ or services, cost reduction and reduction of the customer audits. It also allowed compile others important aspects such as: decrease the rate of incidents, rejections, non-conformities and complaints, increase the profitability; improve the use of time and resources, clear definition of responsibilities; increase their training, increase their participation in the management of the company; improve the work environment; decrease absenteeism; establish cooperation agreements with suppliers; and reduce accidents. On other hand, according to Sampaio (2009), most commonly stated ISO 9001 certification benefits reported in the literature are: access to new markets, productivity improvements, corporate image improvement, product defect rate decreases, market share improvement, quality awareness improvements, ISO 9000 certification as a marketing tool, definition of the personnel responsibilities and obligations, customer relationship improvements, delivery times improvements, customer satisfaction, internal organisation improvements, customer communication improvements, nonconformities decreases, customers' complaints decreases, internal communication improvements, product quality improvement, competitive advantage improvement and personnel motivation.

However, despite the fore mentioned benefits, not all certified companies enjoy these with the same intensity (Escanciano et al., 2008); some firms find that the intensity is felt strongly by larger companies, which are more automated and possess a higher technological level (Vloeberghs and Bellens, 1999). Companies that give importance to certification according to ISO 9001 put a greater emphasis on quality and have a balanced perspective on the internal and external quality (Dick et al., 2001). The list of benefits from the certification is potentially infinite, but some of the benefits of the certification according to ISO 9001 tend to be vague, such as efficiency or good health of the corporate culture, while others may have measurement problems, specifically the increase of productivity or market share (Jones, 1997).

Despite the difficulties regarding the quantification and measurement of benefits, these can be separated into internal and external, relatively to the company (Tsiotras and Gotzamani, 1996). This differentiation is used in research and studies (Vloegeberhgs and Bellen, 1999), but in some investigations, such as performed by Mo y Chan (1997), the internal benefits of certification are the only one's referred. There are different opinions regarding the importance of internal benefits relatively to external ones. Some authors, namely Vloegeberhgs e Bellen (1999), believe that most of the certification benefits (according to ISO 9001) are of internal nature, even when they say, as Brown et al. (1998), that companies are certified for external reasons, in particular SMEs, for whom the improvements obtained with the certification are mostly of internal nature: improvements of quality awareness, improvements of awareness of its problems and improvements of the quality of product. For Quazi and Padijbo (1998), the most important benefits are external, where the top three include: increasing customer satisfaction, improving quality image and market competitiveness, and complying with customer requirements. Understanding the purpose of the ISO 9001 is an important preliminary step in the process of implementation (Taylor, 1995) to achieve the benefits derived from certification. Those benefits that help increase the market share and the export market, clarify the working procedures, improve the quality of the product / service, improve the team work, increase efficiency and reduce customer complaints, emphasizes the continuous improvement, communication and customer satisfaction, return on investments, reduction of transaction costs and quality costs (Krasachol et al., 1998; Lee e Chan, 1999; Zuckerman, 2000; Anderson et al., 1999; Mo e Chan, 1997; Weston, 1995).

On other hand, Boiral $(2012$,a) states that according to the findings made, it is possible to paint a general picture of the main impacts of ISO 9000. These impacts concern internal as well as external aspects. With regard to internal aspects, ISO 9000 certification has been associated with improvements in operation management (productivity, operations efficiency, cost reduction, and so on), quality (nonconformance management, quality control, and so on), organizational effectiveness (internal control, quality-related leadership, and so on), and human resources management (training, communication, and so on). With regard to external aspects, the adoption of ISO 9000 tends to improve customer service (satisfaction, trust, complaints reduction, and so on), supplier relationships (inspection reduction, input quality, and so on), and marketing issues (sales, image, market share, and so on). 
Thus, according to Taríl et al (2012) the three benefits most frequently analyzed by researchers are improved efficiency, improved customer satisfaction and improvements in relations with employees. These are followed by profitability and improved systematization. Other benefits attained by many firms, as analyzed by the studies, are an improvement in market share and sales, image, product/service quality and exports. Conversely, the three benefits least studied are an improvement in competitive position, improved relations with suppliers and improved relations with authorities and other stakeholders.

The ISO 9001 standard is a recognized standard for quality system; although it does not guarantee quality, the ISO certification ensures consistency in the implementation of procedures and promotes the quality, reliability, sustainability and predictability, which are important not only for customers but also for the firm's efficiency and revenue (Goodman, 1998). The implementation of the ISO 9001 in organizations involves multifaceted changes in labour relations and organizational operations, causing a profound difference in how quality is perceived and measured (Elmuti, 1996, Dick et al.,2002). The way to the ISO 9001 certification means hard work and effort, but it is worthwhile. However, it is necessary to have simple and straightforward procedures that everyone can understand (Spreha and Helms, 1995).

Productivity, quality, customer satisfaction and quality of life at work will be improved with the implementation of a quality management system according to the ISO 9001 (Elmuti and Kathawala, 1997; Elmuti, 1996). Regardless of the reasons why firms decide to implement certification measures, the fact that companies are satisfied with the decision to certify and do not discontinue (Jones, 2000) confirms that it is worthwhile. According to several authors (Corbett et al., 2003, Anderson et al. 1999; Buttle and Jayne, 1999; Sun, 1999; Vloeberghs and Bellens, 1999; Brown and Van der Wielle, 1998; Krasachol et al. 1998; Lee and Chan, 1999; Sampaio, 2009; Taríl et al., 2012), the main advantages, of certification according to the ISO 9001, even when considered as a starting point for quality assurance, are "quality improvement", "improved procedures" and "improvement of corporate image", which according to these authors is quite consistent from country to country and from sector to sector.

With this in mind, we conducted an empirical study regarding the motivations of Portuguese companies to certify under the ISO 9001 and the benefits obtained from its implementation. Thus, the aim of this work is to identify the main motivations for Portuguese companies to obtain certification according to the ISO 9001, as well as, their advantages or benefits.

\section{Methodology}

This research began with the drafting of a questionnaire; to test its feasibility a pre-test was administered to a few firms and experts. Some changes were made, as some respondents had some difficulty in responding to some of the questions. The questionnaire was mailed to 426 companies obtained from a database compiled by the Portuguese Institute of Quality (IPQ) with information on accredited companies from the region Minho - the north region of Portugal, that had been certified according to the ISO 9001.The field work was carried out in the years 2007/2008.

Figure 1 shows the different business sectors that participated in this study: $24.6 \%$ belong to textile sector, $15.4 \%$ construction sector, $12.7 \%$ belong to mechanical sector and $39.8 \%$ belong to other sectors, such as the pharmaceutical, food or transports sectors (these last sectors were grouped and classified as "others" due to their low percentage).

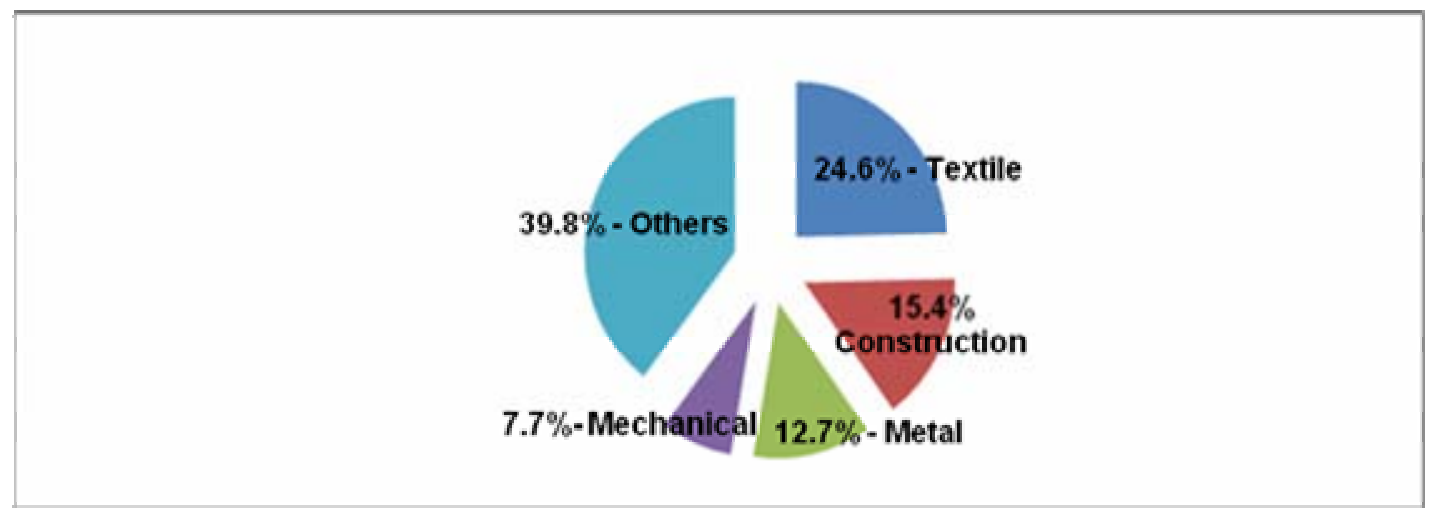

Fig. 1. Firm distribution by business sector

Two hundred and sixty-five completed surveys were received. Five completed surveys were excluded because they were incomplete. Thus, the number of questionnaires in our final sample is 260 , representing a response rate of $61.03 \%$, which is higher than that of other studies that have employed a comparable methodology (Buttle, 1997; Casadesús and Heras, 2001; Corbett et al. 2003; Escanciano, 2000; Heras, 2001; Leal, 1997).

The information for this empirical work was obtained from a questionnaire based on work done by Corbett (2003). In this work, 21,427 firms from 15 different countries (Australia, Canada, France, Hong Kong, Indonesia, Japan, Corey, Malaysia, New 
Zeeland, Filipines, Singapore, Sweden, Taiwan, Thailand and USA) filled out the questionnaire, which led to 5,389 answers; this corresponded to $25.19 \%$ of the total of questionnaires.

The motivation for certification was measured on 11 items while the benefits they received from certification was measured on 13 categories, all of which were expressed on a five-point scale, ranging from 1 for "no benefits" to 5 for "very substantial".

Table 1. Main items of the questionnaire on motivations and benefits of certification.

\begin{tabular}{|c|c|}
\hline \multirow{11}{*}{ Motivations for certification } & Cost reduction \\
\hline & Quality improvement \\
\hline & Marketing advantages \\
\hline & Customer pressure \\
\hline & Many competitors certified \\
\hline & Benefits experienced by other firms \\
\hline & Avoid potential export barrier \\
\hline & Capturing workers' knowledge \\
\hline & Relations with government authorities \\
\hline & Relations with communities \\
\hline & Corporate image \\
\hline \multirow{14}{*}{ Benefits of certification } & Reduction of production costs \\
\hline & Improvement of productivity \\
\hline & Improvement of productivity \\
\hline & Improvement of assurance in the company's quality \\
\hline & Environmental improvements \\
\hline & Increase in "on time" deliveries \\
\hline & Increase in customers satisfaction \\
\hline & Increase in market share \\
\hline & Maintenance / increase in profit margin \\
\hline & Better definition and standardization of working procedures \\
\hline & Improvement in workers' morale \\
\hline & Improvement in the relationship with authorities \\
\hline & Improvement in the relationship with communities \\
\hline & Improvement of corporate image \\
\hline
\end{tabular}

In order to compare our study with the reference study (Corbett, et al., 2003) the "relative" motivations were calculated, as well as the "relative" benefits, by dividing the score in each motivation by the sum of the scores for all motivations or benefits referred by the firms. In our data analysis we employed multivariate analyses (statistical program SPSS 14.0 for windows) based on statistical methods that consider simultaneously multiple measures (variable) for each research item. The multivariate data analyses corresponds to a generalization of univariate and bivariate analyses, making multivariate analyses based on one relation or on a group of relations (Torres, 2005).

The prime objective of this work was to determinate the main motivation for certification according to the ISO 9001, as well as, the main benefits that Portuguese Companies, in the Minho - the north region of Portugal, achieved after they implemented and certified the quality system according to the ISO 9001.

\section{Results and Discussion}

As results of this research are presented, in this paragraph, the main motivations for certification, according to the ISO 9001 , as well as, the main benefits of certification.

\subsection{Motivation for certification}

According to Figure 2, the main motivations for the certification of Portuguese companies in Minho - the north region of Portugal - are, in descending order, "quality improvement" based on the global achievement of companies due to certification; improvement of "corporate image" due to certification; "marketing advantages" due to the increase in the number of customers; "capturing the workers knowledge, as they have a better understanding of how the company works; "cost reduction" due to higher efficiency obtained through certification. As secondary motivations, "relations with the communities" can be considered as an important factor in the social environment of the company; "benefits experienced by others" after certification; "customer pressure" from important customers; and "relationship with the authorities" expecting to be a good argument to improve the 
relationship with the authorities to fulfill the rules; "many competitors certified" which reduces the loss of business against competitors already certified; "avoid potential export barrier" as certifications seems to be a criteria for exportation.

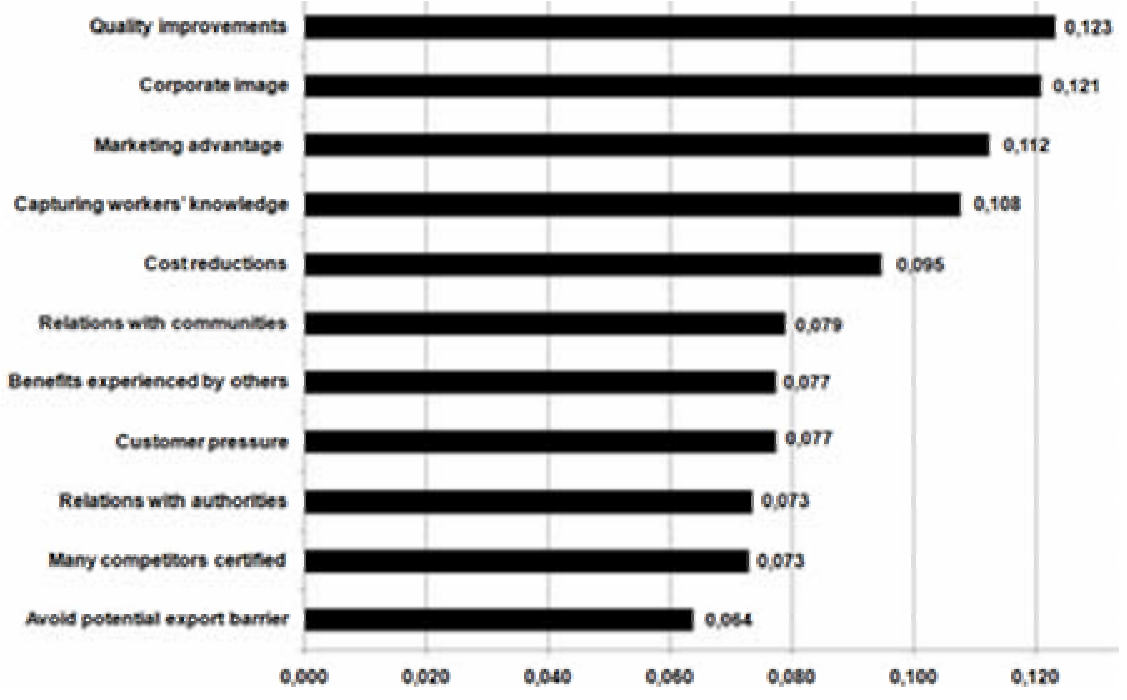

Fig. 2. Motivations for implementing ISO 9001 certification.

\section{2 - Factorial analysis - Motivations}

According to table 2, we obtained a Cronbach's Alpha of 0,772 when we examined the internal consistency analysis of the eleven items used to measure the motivations for a given firm to implement certification; this is a reasonable value.

Table 2. Cronbach's Alpha Score for Firm Motivations

\begin{tabular}{|c|c|c|}
\hline $\begin{array}{c}\text { Cronbach's } \\
\text { Alpha }\end{array}$ & $\begin{array}{c}\text { Cronbach's Alpha } \\
\text { Based on } \\
\text { Standardized Items }\end{array}$ & N of Items \\
\hline .772 & .775 & 11 \\
\hline
\end{tabular}

According to table 3, it is possible to use a factorial model if there is a variable correlation between them. The KMO (KaiserMeyer-Olkin) is a statistical procedure that can help determine the quality of the correlation between variables.

Table 3. Kaiser-Meyer-Olkin of motivations.

\begin{tabular}{|c|c|c|}
\hline \multicolumn{2}{|c|}{$\begin{array}{l}\text { Kaiser-Meyer-Olkin Measure of Sampling } \\
\text { Adequacy. }\end{array}$} & 760 \\
\hline \multirow{3}{*}{$\begin{array}{l}\text { Bartlett's Test of } \\
\text { Sphericity }\end{array}$} & Approx. Chi-Square & 616.482 \\
\hline & Df & 55 \\
\hline & Sig. & .000 \\
\hline
\end{tabular}

In Table 4, we have a KMO of 0,760, which suggests a medium correlation, allowing us to undertake factorial analyses. 
Table 4. Principal Component Analysis of Firm Motivations.

\begin{tabular}{|c|c|c|c|c|c|c|c|c|c|}
\hline \multirow[t]{2}{*}{ Component } & \multicolumn{3}{|c|}{ Initial Eigenvalues } & \multicolumn{3}{|c|}{$\begin{array}{c}\text { Extraction Sums of Squared } \\
\text { Loadings }\end{array}$} & \multicolumn{3}{|c|}{$\begin{array}{c}\text { Rotation Sums of Squared } \\
\text { Loadings }\end{array}$} \\
\hline & Total & $\begin{array}{c}\text { \% of } \\
\text { Variance }\end{array}$ & $\begin{array}{c}\text { Cumulative } \\
\%\end{array}$ & Total & $\begin{array}{c}\% \text { of } \\
\text { Variance }\end{array}$ & $\begin{array}{c}\text { Cumulative } \\
\%\end{array}$ & Total & $\begin{array}{c}\text { \% of } \\
\text { Variance }\end{array}$ & $\begin{array}{c}\text { Cumulative } \\
\%\end{array}$ \\
\hline 1 & 3.483 & 31.659 & 31.659 & 3.483 & 31.659 & 31.659 & 2.391 & 21.736 & 21.736 \\
\hline 2 & 1.531 & 13.918 & 45.577 & 1.531 & 13.918 & 45.577 & 1.967 & 17.882 & 39.619 \\
\hline 3 & 1.096 & 9.964 & 55.541 & 1.096 & 9.964 & 55.541 & 1.425 & 12.956 & 52.575 \\
\hline 4 & 1.028 & 9.344 & 64.885 & 1.028 & 9.344 & 64.885 & 1.354 & 12.311 & 64.885 \\
\hline 5 & .835 & 7.590 & 72.475 & & & & & & \\
\hline 6 & .726 & 6.600 & 79.075 & & & & & & \\
\hline 7 & . 647 & 5.882 & 84.957 & & & & & & \\
\hline 8 & .545 & 4.954 & 89.911 & & & & & & \\
\hline 9 & .433 & 3.937 & 93.848 & & & & & & \\
\hline 10 & .395 & 3.594 & 97.442 & & & & & & \\
\hline 11 & .281 & 2.558 & 100.000 & & & & & & \\
\hline
\end{tabular}

The number of variables are reduced to 4 , which explain the $64,88 \%$ of the variance of the construct. It is necessary to describe them and using a Varimax rotation, according to Table 5, we have:

Table 5. Varimax Rotation

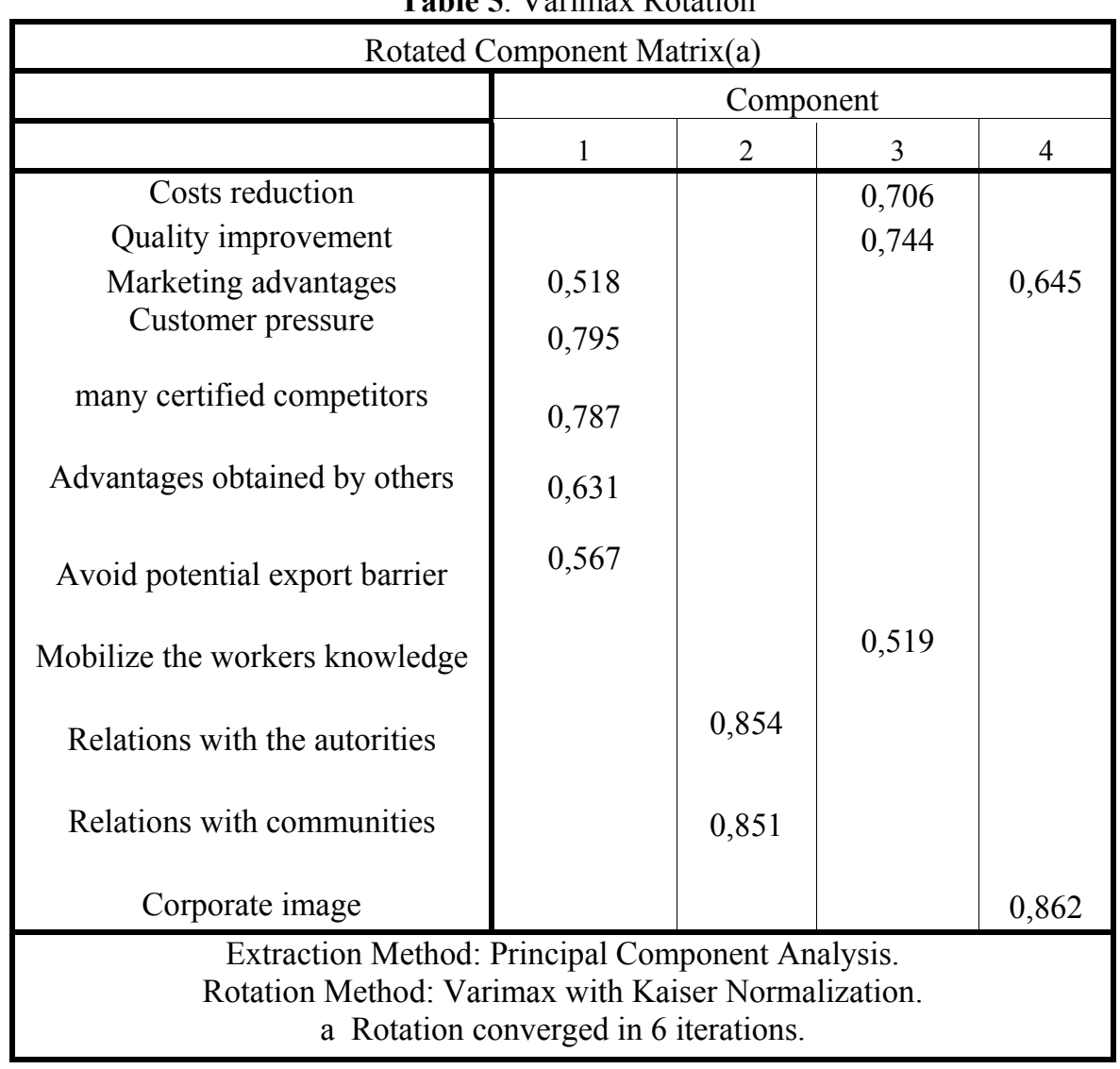

From the analysis of the results in Table 5, the companies' certification is mainly due to four reasons:

1 - Reaction - customer pressure, many competitors certified, advantages obtained by others due to certification, avoid potential export barrier; 
2 - Political reasons - relationships with the authorities and with communities;

3 - Efficiency - cost reduction, quality improvement and capturing the workers knowledge;

4 - Market - marketing advantages and corporate image.

In sum, we can conclude that companies' certification is due to internal reasons (efficiency) and external reasons (reaction, political and marketing reasons).

\subsection{Benefits of certification}

According to Figure 3, the main benefits for certified Portuguese companies in Minho region, are, in descending order: "procedures", that is, improvement of the definition and standardization of working procedures; "image" based on the improvement of corporate image as result of certification; "quality" based on the improvement of assurance in the company's quality; increase in "customer satisfaction" and "on-time delivery"; increase in workers" "morale" and in productivity; increase in market share; decrease in "production costs"; improvement in community relationships; improvement in the relationship with authorities; finally "profit margin" was considered the least important benefit.

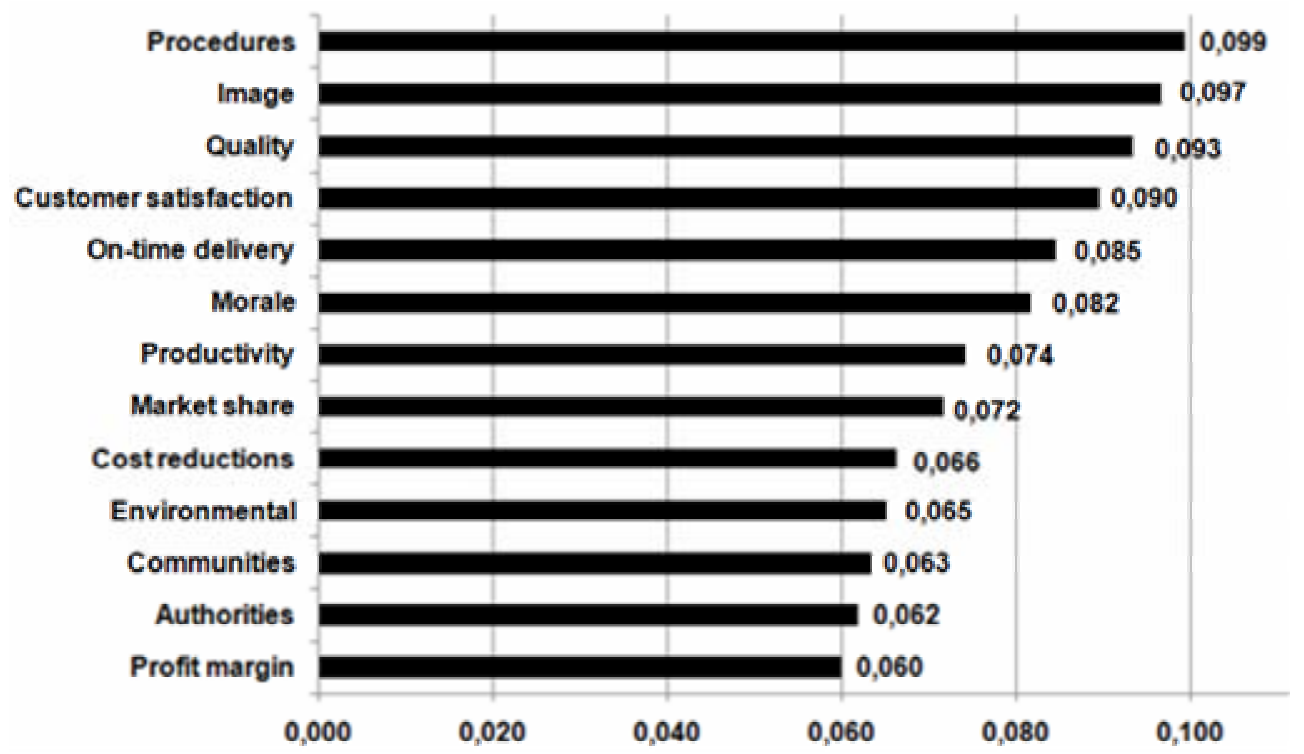

Fig. 3. Benefits in implementing the ISO 9001 certification.

\subsection{Factorial analysis}

With the analysis of internal consistency of the thirteen items that evaluate the motivations for companies' certifications, a Cronbach's Alpha of 0.894 is obtained, that means good.

Table 6. Cronbach's Alpha of Benefits

\begin{tabular}{|c|c|c|}
\hline $\begin{array}{c}\text { Cronbach's } \\
\text { Alpha }\end{array}$ & $\begin{array}{c}\text { Cronbach's Alpha Based on } \\
\text { Standardized Items }\end{array}$ & N of Items \\
\hline 0.894 & 0.898 & 13 \\
\hline
\end{tabular}

The factorial model can be applied if there is a correlation between variables; the KMO is one of the statistical procedures that can help define the quality of the correlation between the variables.

Table 7. Kaiser-Meyer-Olkin of benefits

\begin{tabular}{|c|c|c|}
\hline \multicolumn{2}{|c|}{$\begin{array}{l}\text { Kaiser-Meyer-Olkin Measure of Sampling } \\
\text { Adequacy. }\end{array}$} & .886 \\
\hline \multirow{3}{*}{$\begin{array}{l}\text { Bartlett's Test of } \\
\text { Sphericity }\end{array}$} & Approx. Chi-Square & 1424.242 \\
\hline & Df & 78 \\
\hline & Sig. & .000 \\
\hline
\end{tabular}


A KMO of 0,886 suggests a good correlation and thus enables undertaking factorial analysis.

Table 8. Principal Component Analysis of benefits.

\begin{tabular}{|c|c|c|c|c|c|c|c|c|c|}
\hline Component & \multicolumn{3}{|c|}{ Initial Eigenvalues } & \multicolumn{3}{|c|}{$\begin{array}{c}\text { Extraction Sums of Squared } \\
\text { Loadings }\end{array}$} & \multicolumn{3}{|c|}{$\begin{array}{c}\text { Rotation Sums of Squared } \\
\text { Loadings }\end{array}$} \\
\hline & Total & $\begin{array}{c}\% \text { of } \\
\text { Variance }\end{array}$ & $\begin{array}{c}\text { Cumulative } \\
\%\end{array}$ & Total & $\begin{array}{c}\% \text { of } \\
\text { Variance }\end{array}$ & $\begin{array}{c}\text { Cumulative } \\
\%\end{array}$ & Total & $\begin{array}{c}\% \text { of } \\
\text { Variance }\end{array}$ & $\begin{array}{c}\text { Cumulative } \\
\%\end{array}$ \\
\hline 1 & 5.892 & 45.320 & 45.320 & 5.892 & 45.320 & 45.320 & 3.163 & 24.328 & 24.328 \\
\hline 2 & 1.166 & 8.966 & 54.286 & 1.166 & 8.966 & 54.286 & 2.669 & 20.531 & 44.859 \\
\hline 3 & 1.112 & 8.552 & 62.838 & 1.112 & 8.552 & 62.838 & 2.337 & 17.979 & 62.838 \\
\hline 4 & .889 & 6.835 & 69.673 & & & & & & \\
\hline 5 & .782 & 6.016 & 75.689 & & & & & & \\
\hline 6 & .658 & 5.060 & 80.749 & & & & & & \\
\hline 7 & .523 & 4.026 & 84.776 & & & & & & \\
\hline 8 & .438 & 3.369 & 88.145 & & & & & & \\
\hline 9 & .413 & 3.180 & 91.325 & & & & & & \\
\hline 10 & .356 & 2.736 & 94.060 & & & & & & \\
\hline 11 & .286 & 2.203 & 96.263 & & & & & & \\
\hline 12 & .256 & 1.970 & 98.234 & & & & & & \\
\hline 13 & .230 & 1.766 & 100.000 & & & & & & \\
\hline
\end{tabular}

In other words, the variables are reduced to three main categories which explains $62,83 \%$ of the variance of the construct; using a Varimax rotation, the results are obtained, according to table 9.

The three main factors that reflect the benefits obtained from certification according to the ISO 9001 are:

1-Global profitability - reduction of production costs, increase in productivity, increase in on-time deliveries; improvement in market share; maintenance / increase of profits;

2-Political benefits - relation with the authorities; relation with community and improved environmental performance;

3-Improvement of marketing image and internal confidence - improvement of confidence on the company's quality; improvement in costumers' satisfaction; improvements in the definition and standardization of working procedures; increase in workers' moral; improvement of company image.

Table 9. Varimax Rotation of the benefits

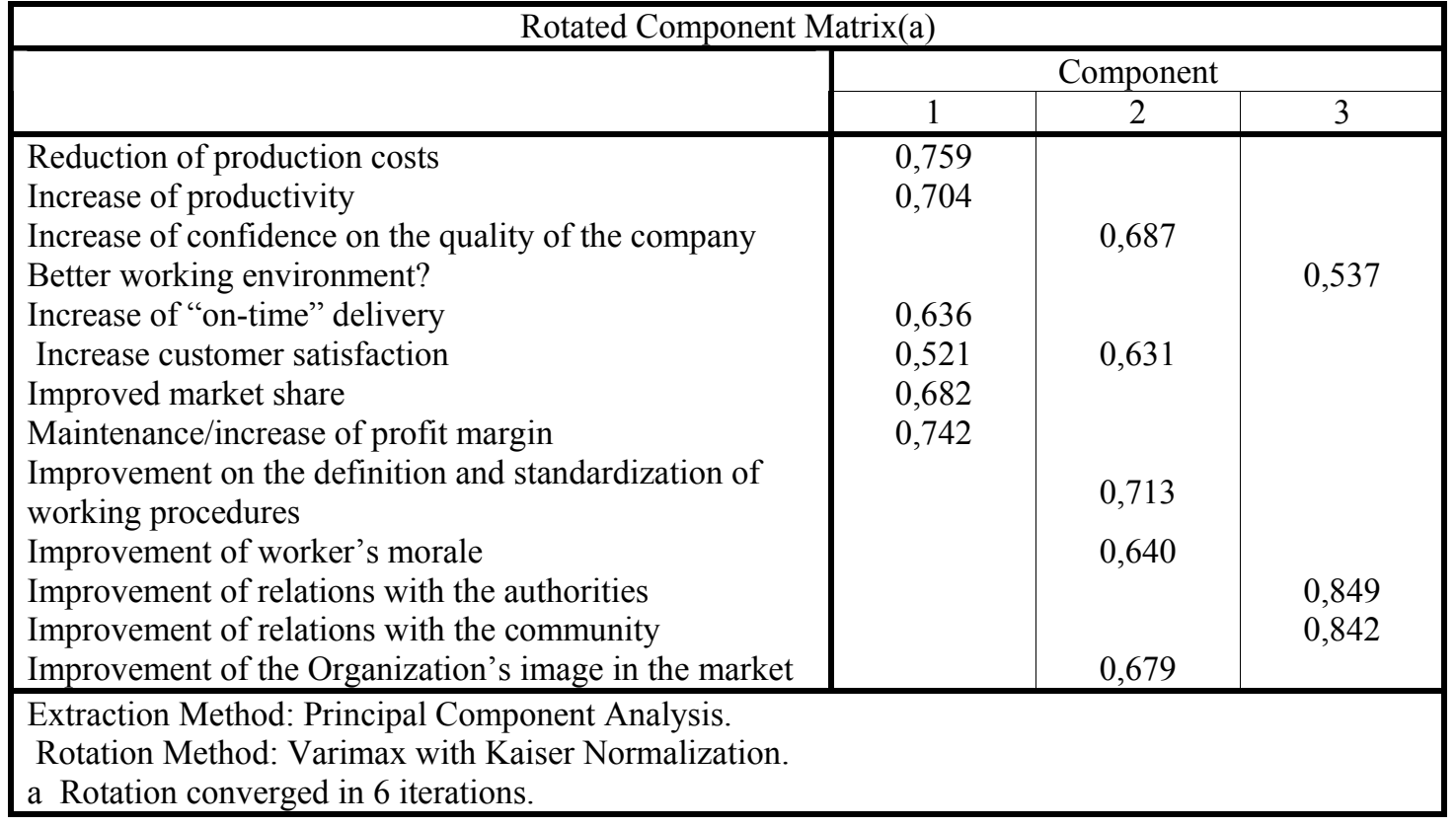




\section{Discussion}

There are many studies on why companies choose certify their quality systems according to the ISO 9001, such as: (Anderson e Johnson, 1999; Buttle, 1997; Casadesus e Gimenez, 2000; Carlsson e Carlsson, 1996; Escanciano et al., 2001; Yahya e Goh, 2001; Jones et al., 1997; Llopis e Tari, 2003; Meegan e Taylor, 1997; Tsiotras e Gotzamani, 1996; Vloeberghs, 1999), many of them with equivalent obtained results. The motivations for certification according to the ISO 9001 vary slightly from country to country. The main motivations of firms in Portugal to be certified according to the ISO 9001 are in a descending order "quality improvement", "corporate image" and "marketing advantage", as found in Japan, Canada, Korea, Australia, New Zealand, Indonesia, Malaysia, Philippines, Singapore and Thailand. This finding is in line with work done by Corbett et al. (2003). This is also considered the results when the set of the 15 economies studied by Corbett et al.(2003). The first three motives are in accordance with our study, while the fourth motivation that appears in our study is different from the one found by Corbett et al. (2003). In our study we found that the fourth motivation was mobilizing workers'knowledge, as found in Japan. In Corbett et al.'s (2003) study, the motivation ranked in fourth place was "customer pressure", as found in Sweden, Canada, United States, Korea, Hong Kong, Indonesia, Malaysia, Philippines, Singapore and Thailand. Also according to Buttle (1997), there are marketing reasons, namely those related to external customers, which provide evidence that companies expect the ISO 9001 to become a requirement to gain customers. In comparison with other studies, the reasons and factors that lead companies to certifiy themselves can be grouped into internal and external reasons (Escanciano et al., 2001).

The external pressure, the certification needs of competitors and advertising are factors behind certifications (Gotzamani e Tsiotras, 2002; Lipovatz et al., 1999; Jones, 1997), while others consider certification as part of a larger program in order to improve quality, productivity and internal efficiency (Llopis e Tari, 2003). Overall, we can say that Portuguese companies certify by internal factors (efficiency) and external factors (reaction, marketing and political reasons). Identical findings get Casadesús e Heras (2001) that concluded that companies ensure: efficiency (improving the overall quality and operational), market (improving the company's position in the market), anticipation (ability to perceive opportunities) and reaction (demand/pressure from customers, competitors certificated). And according Tsiotras e Gotzamani (1996), companies make sure to: improve internal productivity, organization and updating the quality management system, improve the image and reputation, facilitate and simplify procedures and contacts with customers and satisfy the external demands and market pressures. Companies are generally satisfied with certification. But while some studies indicate that the benefits obtained are mainly organizational, others highlight exclusively business advantages in the participation of personal (Heras et al., 2000; Casadesús e Heras, 2001).

The benefits obtained with the certification of the quality system according to the ISO 9001, despite the difficulties, considering the quantification and measurement of benefits of certification, these can be divided into internal and external benefits to the company (Tsiotras e Gotzamani, 1996, Vloegeberhgs e Bellen, 1999). Concerning external benefits, the implementation and certification of a quality system allows the company to be recognized for its quality by an independent entity (Martinez et al., 2000). The three main benefits for Portuguese companies obtained with certification of quality systems are, in descending order: "procedures", that means improvement of definition and standardization of working procedures; "image" based on improvement of corporate image as result of certification; "Quality" based on the guarantee in the company quality system, more or less, as the economies studied by Corbett et al.(2003), except Hong Kong and Taiwan that put in the first place "improvement of company image". One of the most important internal benefits, according to Corbett et al. (2003), is the improvement of procedures. This benefit was not initially explicitly, but it is unquestionably, very enjoyable (Casadesús e Heras, 2001; Heras et al., 2000; Carlsson e Carlsson, 1996) and it is in line with our study. This is also the most appreciated benefit reported in the United States, followed by companies from Australia, Canada and France (Corbett et al., 2003). The referred benefit, "improvement of procedures" appeared in fifth place in a study carried out by Zaramdini (2007) in 209 companies from the United Arab Emirates, where in first place they found "Increase productivity and/or efficiency". Companies are generally satisfied with the certification, even when their expectations are not completely satisfied. According to Corbett et al. (2003) the main advantages of certification, even when considered as a starting point for quality assurance, are "quality improvement", "improved procedures" and "corporate image", which is fairly consistent from country to country. Thus, the main advantages and benefits of certification according to the ISO 9001, even when considered as a starting point for quality assurance, are fairly consistent from country to country and from sector to sector of activity (Corbett et al., 2003; Anderson et al., 1999; Buttle e Jayne, 1999; Sun, 1999; Vloeberghs e Bellens, 1999; Brown e Van der Wielle, 1998; Marrom e Van der Wiele, 1995; Krasachol et al., 1998; Lee e Chan, 1999).

\section{Conclusions}

Although the volunteer character of the standard ISO 9001 having a quality system according to this standard and certification is a "must" for firms that want to be recognised for their quality and to survive in an increasingly competitive market.

The objectives of this research were to identify the main motivations for the certification of the Portuguese companies and the main benefits obtained.

The main motivations for the ISO 9001 certification for Portuguese companies are the "improvement of quality", "corporate image", "commercial advantages"; globally, we can say that the certification of Portuguese companies is due to internal factors (efficiency) and external factors (reaction, political reasons and marketing). 
The main benefits of certification are "improvement in the definition and standardization of working procedures", "improvement in company's image", "improvement in the confidence in the quality of the company" and "improvement in customer satisfaction" and globally we can say that the factors that benefit Portuguese companies after certifications are global profitability; political benefits and improvement of commercial image and internal confidence.

Certification may not increase a firm's market share or profits, but it definitely does not decrease market share or profitability. Secondly, perhaps the most important benefit of the ISO 9001 is the improvement of procedures.

Our study did not explicitly ask about the improvement of procedures as a motivation for certification, but the evidence based on the questionnaire administered to the certified companies suggests that in many cases this advantage was not expected but was nonetheless very useful.

\section{Acknowledgement}

The authors would like to thank the Portuguese companies that participated in this research and that kindly answered the questionnaires.

\section{References}

Anderson E.A., Adams D.A., 1997. Evaluating the success of TQM implementation: lessons from employees. Production and Inventory Management Journal, Vol. 38, No. 4, pp.1-6.

Anderson J.C., Rungtusanatham, M., Schroeder, R.G., 1994. A theory of quality management underlying the Deming management method. The Academy of Management Review, Vol.19, No. 3, pp. 472-509.

Anderson S.W, Daly J.D., Johnson M.F., 1999. Why firms seek ISO 9000 certification: Regulatory compliance or competitive advantage? Production and Operations Management, Vol. 8, No. 1, pp. 28-42.

Anserdon S., 2001. Certification du systéme de management + stratégie d'entreprise en commerce électronique $=$ cyberassurance. ISO Management Systems, Octobre.

Bellis-Jones R., Hand M., 1989. Are total quality management programmes a fact or a management fal?. Management Accounting, Vol. 67, No. 5, pp. 36-39.

Boiral O., 2012,a. ISO 9000 and Organizational Effectiveness: A Systematic Review. QMJ Vol. 19, No. 3, pp.16-37.

Boiral O., 2012,b. ISO Certificates as Organizational Degrees? Beyond the Rational Myths of the Certification Process. Organization Studies, Vol. 33, No. (5-6), pp. 633-654.

Brown A., Wiele, T., Loughton K., 1998. Smaller enterprises' experiences with ISO 9000. The International Journal of Quality \& Reliability Management, Vol.15, No 3, pp. 273.

Brown J.O., 1999. ISO 9000 Basics. Quality Progress, Vol. 32, No 3, pp.110.

Brown M.G.,1997. Measuring up against the 1997 Baldrige criteria. The Journal for Quality and Participation. Vol.20, No. 4, pp. 22-29.

Brown R.,1994. Does America need ISO 9000? Machine Design, Vol. 66, No. 11, pp. 70-74.

Buttle F.A., Jayne M.R.,1999. ISO 9000: is the real estate sector any different? Property Management, Vol. 17, N. 2 ; pp. 125.

Carlsson M., Carlsson D.,1996. Experiences of implementing ISO 9000 in Swedish industry. The International Journal of Quality \& Reliability Management, Vol. 13, No. 7, pp. 36.

Casadesús M., Gimenez G., 2000. The benefits of the implementation of the ISO 9000 standard: empirical research in 288 Spanish companies. The TQM Magazine, Vol. 12, No. 6, pp. 432.

Casadesús M., Heras I.,2001. La norma ISO 9000: benefícios de su introducción en las empresas españolas. Un estudio empírico. Revista Europea de Dirección y Economía de la Empresa, Vol. 10, No. 1, pp. 55-68.

Corbett C., Luca A.M., Pan J. 2003. Perspectives globales sur des normes mondiales - Étude de l'ímpact d'ISO 9000 et d'ISO 14000 dans 15 économies. ISO Management Systems, janvier-février, pp. 27-36.

Corbett C.J., Montes M.J., Kirsch D.A., Gil M.J.A.,2002. La certification ISO 9000 est-il rentable? ISO Management Systems, Juillet-Août, pp. 25-34.

Costa B., 2008. Sistemas de Gestión de la Calidad en las Empresas Portuguesas: Implantación, Impacto y Rendimiento. Doctoral Thesis, University of Seville, Spain.

Dick G., Gallimore K., Brown J.C.,2002. Does ISO 9000 accreditation make a profound difference to the way service quality is perceived and measured? Managing Service Quality, Vol. 12, No. 1, pp. 30-43.

Elmuti D., Kathawala Y.,1997. An investigation into the effects of ISO 9000 on participants' attitudes and job performance. Production and Inventory Management Journal, Vol. 38, No 2, pp. 52-58.

Escanciano C.M., Sánchez Fernández E.F., Ordás C.V.,2001. La relación entre el coste y los beneficios de la certificación ISO 9000: Resultados de un estudio empírico. Revista Investigaciones Europeas de Dirección y Economía de la Empresa, Vol. 7 No. 1, pp.135-146.

Escanciano C.M.,2000. Factores relacionados com a recuperação do investimento na certificação ISO 9000. Revista de Economia y Empresa, No 39, Vol. XIV (2ª́poca, 2a Cuatrimestre), pp. 11 -28. 
Goodman D.1998. Thinking export? Think ISO 9000. World Trade, Vol. 11, No 8; pp. 48-50.

Gotzamani K.D., Tsiotras G.D.,2001. An empirical study of the ISO 9000 standards' contribution towards total quality management. International Journal of Operations \& Production Management, Vol. 21, No 9/10, pp. 1326-1343.

Gotzamani K.D., Tsiotras G.D.,2002. The true motives behind ISO 9000 certification: Their effect on the overall certification benefits and long term contribution towards TQM. The International Journal of Quality \& Reliability Management, Vol. 19, No 2/3, pp. 151-170.

Hardjono T.W., Have S.T., Have W.D.,1997. The European Way to Excellence. How 35 European manufacturing, public and service organizations make use of quality management. European commission, Ed. Directorate-General III Industry, Bruselas.

Heras I., Casadesus M., Dick G.P.M.,2002. ISO 9000 certification and the bottom line: A comparative study of the profitability of Basque region companies. Managerial Auditing Journal, Vol. 17, No 1/2, pp. 72-79.

Heras I., Dick G.P.M., Casadesus M.,2002. ISO 9000 registration's impact on sales and profitability: A longitudinal analysis of performance before and after accreditation. The International Journal of Quality \& Reliability Management, Vol. 19, No 6/7, pp. 774-792.

Heras I., Ochoa C., Arana P., 2000. Análisis empírico de la incidencia de la normativa ISO 9000 en la rentabilidad de las empresas. Revista de Economía y Empresa, Vol. XIV, No 39, (2 $2^{\mathrm{a}}$ Época, $2^{\circ}$ Cuatrimestre $)$.

Heras-Saizarbitoria I., Boiral O., 2013,a. ISO 9001 and ISO 14001: Towards a research agenda on management system standards. International Journal of Management Reviews, Vol. 15, pp. 47-65.

Heras-Saizarbitoria I., Boiral O., 2013,b. Symbolic adoption of ISO 9000 in small and medium-sized enterprises: The role of internal contingencies. International Small Business Journal. DOI: 10.1177/0266242613495748, pp.1-22.

Jones, K., 2000. No regrets about ISO certification. Electrical Apparatus, Vol. 53, No. 9, pp. 35-37.

Jones R., Arndt G., Kustin R.,,1997. ISO 9000 among Australian companies: impact of time and reasons for seeking certification on perceptions of benefits received. The International Journal of Quality \& Reliability Management, Vol.14, No. 7, pp. 650.

Krasachol L., Willey P.C.T, Tannock J.D.T., 1998.The progress of quality management in Thailand.The TQM Magazine, Vol. 10, No. 1, pp. 40.

Leal Millán, A. 1997.Gestión de Calidad Total en Empresas Españolas: Un Análisis Cultural y de Rendimiento. Revista Europea de Dirección y Economía de la Empresa, Vol. 6, No 1, pp. 37-56.

Leal A., Amador F., Ramirez J.,1997. Total Quality Management in Action: Implementing Ways in Spanish Companies. Managing in Uncertainty: Theory and Practice. Kluwer Academic Publishers. Netherlands, pp. 357-377.

Leal A., Roldán J.,2001. Benchmarking and Knowledge Management: A European Approach. Operational Research Insight, Vol. 14, No 4, pp. 11-22.

Leal A., Roldán, J., Acedo F., 2002. Quality culture and performance: A Cameron's framework test in Spanish companies. Proceedings of the 2nd Annual Conference on Innovative Research in Management (European Academy of Management), Stockholm - Sweden.

Lee S.F., Roberts P., Lau W.S., 1999. Survey on ISO 9000 quality management system implementation in Hong Kong. Managerial Auditing Journal, Vol. 14, No. 1/2, pp. 79.

Lee T.Y., Leung H.K.N., Chan K.C.C.,1999. Improving quality management on the basis of ISO 9000.The TQM Magazine, Vol. 11, No 2, pp. 88.

Leung H.K.N., Chan K.C.C., Lee T.Y., 1999. Costs and benefits of ISO 9000 series: a practical study. The International Journal of Quality \& Reliability Management, Vol. 16, No 7, pp. 675.

Lipovatz, D., Stenos F., Vaka A., 1999. Implementation of ISO 9000 quality systems in Greek enterprises. The International Journal of Quality \& Reliability Management, Vol. 16, No 6, pp. 534.

Llopis, J., Tari J.J.,2003. The importance of internal aspects in quality improvement. The International Journal of Quality \& Reliability Management, Vol. 20, No. 2/3, pp. 304-325.

Martinez F., Balbastre B., Escriba M., Gonzalez C., Pardo M., 2000. Analysis of the implementation of ISO 9000 quality assurance systems. Work Study, Vol. 49, No 6, pp. 229.

Meegan S.T.1997. A model for managing the transition from ISO 9000 to TQM. Training for Quality, Vol. 5, No 1, pp. 35.

Meegan S.T., Taylor W. A., 1997. Factors influencing a successful transition from ISO 9000 to TQM. The influence of understanding and motivation. The International Journal of Quality \& Reliability Management, Vol. 14, No. 2, pp. 100.

Mo J.P.T., Chan A.M.S.,1997. Strategy for the successful implementation of ISO 9000 in small and medium manufacturers. The TQM Magazine, Vol. 9, No. 2, pp. 135.

Quazi H.A., Padibjo S.R.,1997. A journey towards total quality management through ISO 9000 certification - a Singapore experience. The TQM Magazine, Vol. 9, No 5, pp. 364.

Quazi H.A., Pdibjo S.R., 1998. A journey toward total quality management through ISO 9000 certification - a study on small and medium-sized enterprises in Singapore. The International Journal of Quality \& Reliability Management, Vol. 15, No 5, pp. 489.

Sampaio P., Saraiva P., Rodrigues A. G., 2009. ISO 9001 certification research: questions, answers and approaches. International Journal of Quality \& Reliability Management Vol. 26 No. 1, pp. 38-58.

Santos G., Mendes F., Barbosa J., 2011.Certification and integration of management systems: the experience of Portuguese small and medium enterprises. Journal of Cleaner Production, No. 19, pp.1965-1974. 
Spreha S.A., Helms M.M.,1995. ISO 9000 - A struggle well worth the effort. Production and Inventory Management Journal, Vol. 36, No 4, pp. 46-53.

Tarí1 J.J., Molina-Azorín J. F., Heras I., 2012. Benefits of the ISO 9001 and ISO 14001 standards: A literature review. Journal of Industrial Engineering and Management, Vol. 5, No. 2, pp. 297-322.

Taylor W.A., 1995. Organizational differences in ISO 9000 implementation practices. The International Journal of Quality \& Reliability Management, Vol. 12, No 7, pp. 10-28.

Taylor W.A., Meegan S.T. 1997. Senior executives and the ISO 9000-TQM transition A framework and some empirical data. The International Journal of Quality \& Reliability Management, Vol. 14, No7, pp. 669.

Tsiotras G., Gotzamani K., 1996. ISO 9000 as an entry key to TQM: the case of Greek industry. The International Journal of Quality \& Reliability Management, Vol. 13, No. 4, pp. 64.

Vloeberghs D.B., Bellens J., 1999. Implementing the ISO 9000 standards in Belgium. Quality Progress, Vol. 29, N. 6, pp.43-48.

Weston F.C.,1995. What do managers really think of the ISO 9000 registration process? Quality Progress, Vol. 28, No. 10, pp. 6774.

Yahya S., Goh W.,2001. The implementation of an ISO 9000 quality system. The International Journal of Quality \& Reliability Management, Vol. 18, No 8/9, pp. 941-967.

Zaramdini W., 2007. An empirical study of the motives and benefits of ISO 9000 certification: the UAE experience. International Journal of Quality \& Reliability Management, Vol. 24, No. 5, pp. 472-491.

Zuckerman A., 2000. Start preparing for revised ISO 9000 standards. Metal Center News, Vol. 40, No11, pp. 5-7.

Zuckerman A., 1999. ISO 9000 revisions are key to knowledge age excellence. Quality Progress, Vol. 32, No. 7, pp. 35-40.

Zuckerman A., 2001. ISO 9000: 2000 now official. World Trade, Vol. 14, No 4, pp. 68-70.

\section{Biographical notes}

G. Santos graduated in Mechanical Engineering (1985) by the Technical University in Lisbon. He completed a post - graduate course in Quality Engineering by the New University of Lisbon (1991) and he received a PhD in Mechanical Engineering - Production Technologies (branch - Industrial Quality) by the University of Minho, in 1999. Presently he is a professor at College of Technology of Polytechnic Institute Cavado Ave in Portugal, where is a Director of a Master Course "Integrated Management Systems QES (Quality, Environment and Safety)". In 2004, November 27, Gilberto has been distinguished by the Board of the Portuguese Engineer Association with the "Senior Member" and in 2006, November 17, has been distinguished by Yorker International University with the Honorary Doctorate of Mechanical Engineering. In 2011, October 15, he received the Badge of Silver by the 25 years as a member of Portuguese Engineer Association. His research interests include Quality, Environment, Safety and Social Responsibility Management Systems, as well as, their integration.

B. Costa graduated in Electrical Engineering by the University of Porto (1977). He received a PhD in Business Management by University of Seville (2008). Presently he is a Professor at College of Management (Polytechnic Institute Cavado Ave) in Portugal. Baptista da Costa is author of many papers presented in Conferences and has participated in congresses as author of papers. His main research interests include strategy and quality management.

A. Leal graduated in Economy and Business Management (1980) by the University of Seville, Master Sc. in European Economy (1982) and PhD in Business Management (1986) by the University of Seville. Presently he is a full Professor and the Head of the Management and Marketing Department at the University of Seville. His research topics include quality management, organizational culture, knowledge management and firm innovativeness. His principal area of research relates to the management of knowledge and organizational culture in complex, dynamic knowledge domains. He has supervised several national projects and many completed PhD projects. Antonio Leal has been published widely in leading journals and has authored many book chapters. His research is published in several top ranked journals including the Journal of Knowledge Management, Management Decision, British Journal of Management, Industrial Marketing Management, International Journal of Technology Management, Total Quality Management, Journal of Organizational Change Management, International Journal of Manpower, The Service Industries Journal, etc. He has developed professional projects about total quality management, and knowledge management in industries including banking, health care and professional sport.

Received December 2013

Accepted May 2014

Final acceptance in revised form May 2014 